\title{
A Comparative Study Of Online Retailing: U.S. Vs. E.U. Consumer Attitudes Toward Product Country Of Origin
}

\author{
Norman E. Pence (E-mail: pencen@mscd.edu), Metropolitan State College of Denver \\ Judith DeLouche Scott, Metropolitan State College of Denver \\ C. Richard Scott, Metropolitan State College of Denver
}

\begin{abstract}
As a first-mover into the use of the Internet for e-commerce, many U.S. retailers have found another tool that it has added to the plethora of methods it can use to reach customers. Although in an early stage of development, the growth of e-commerce is likely to mushroom. Trailing the U.S. in Internet marketing, retailers in the European Union (E.U.) are quickly realizing its potential to increase revenues and profits. This study focuses on two aspects of online retailing by contrasting the perceptions of U.S. and E.U. consumers on the use of the Internet for shopping, and contrasting their views with respect to where a product originates. The study surveyed 268 people from either the U.S., E.U., and from a handful of other locations. From the gathered data set findings and conclusions were made that should be of interest to professionals in academe or the commercial business sector.
\end{abstract}

\section{Introduction}

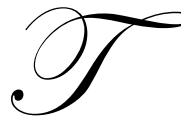

o say that meteoric rise of online retailing has quickly transformed the marketing retailing process would be a major understatement. Whereas the Internet was once a tool reserved for academic exchanges, it has rapidly emerged as a new channel of commercial interaction between buyers and sellers. From any place in the world, sellers can create an inexpensive website to display their wares while consumers can browse/shop these websites from their homes or workplaces. According to a recent report (European Telework Development, 2000) the growing popularity of e-commerce is caused by three driving forces:

- Greatly reduced start-up and running costs for online as opposed to conventional marketing and sales methods.

- $\quad$ Global reach without the need for a local presence in distant markets.

- $\quad$ Easy and competitively priced access to global delivery services.

In today's world a consumer who is armed with a computer and an Internet Service Provider, literally has the world at his or her fingertips. And according to former U.S. Vice President Albert Gore, Jr., the evolution of electronic commerce (e-commerce) is only in the introductory stage of its life cycle. He wrote that:

Soon electronic networks will allow people to transcend the barriers of time and distance and take advantage of global markets and business opportunities not even imaginable today, opening up a new world of economic possibility and progress (Gore, 1999).

Evidence that e-commerce is only in the beginning phase of what it will likely become is shown by e-commerce sales statistics. According to U.S. Census Bureau data reported by Matthew Clark (Electronic News, 2002), e-commerce sales for 2001 only accounted for one percent of the total sales in the United States. Although e-commerce sales represent a small fraction of the total sales, they still accounted for $\$ 32.6$ billion - and that is not small potatoes! Added to the information from the U.S. Census Bureau is the noteworthy statistic revealing that from 2000 to 2001 total ecommerce sales jumped a remarkable 19 percent, while total retail sales only went up 3.3 percent during the same period (U.S. Department of Commerce, The Census Bureau, 2002). 
Of course, as more and more people around the globe get connected to the Internet, intuition tells us that worldwide e-commerce sales are bound to soar. According to CommerceNet (2002), by the end of 2002, approximately 490 million households will be connected to the Internet worldwide. According to the same source, by year-end 2005 Internet connections will nearly double, to approximately 765 million. In order to ensure that increased Internet linkages are transformed from online shoppers to online purchasers, sellers must provide specific features on their web sites to make online shopping a positive experience. In a report rendered by PricewaterhouseCoopers LLP (2001), certain features were identified as most likely to increase likelihood of purchasing from an online source. The importance of these features are rank-ordered as follows:

1. "Close-up" product images.

2. Product availability.

3. Product comparison guides.

4. Search function.

5. Toll-free telephone number to contact customer service representative.

6. Products reviews/evaluation by online shoppers.

Comparatively, the U.S. is a technologically-advanced country and was the first-mover into the commercial use of the Internet. Because of technological development in telecommunications and the resulting availability of the Internet to the majority of its citizens, the U.S. is likely to maintain its position as the leader of the e-commerce pack for some time to come. According to Hobley (2001), almost 34 percent of all Americans had purchased something online by October 2000. And with approximately 59 percent of the U.S. population, using the Internet at home, work, or school (Hobley, 2001) and more than 40 percent of American households connected directly to the Internet (Ernst \& Young, 2001) and with about two million new Internet users added per month (U.S. Department of Commerce, Economics and Statics Administration, 2002), the rest of the world will be hard-pressed to catch up.

Second after the dominant U.S. position in Internet usage, 34 percent of E.U. citizens have some form of Internet access. Of that number, however, less than 8 percent of the population have made an online purchase (Hobley, 2001). But, after the 2001 Christmas season, it was reported (McDonald, 2002) that most E.U. countries saw an increase of more than 40 percent in the number of Christmas shoppers going online. Still with the U.S. lead in Internet usage for commerce, it is only natural to assume that U.S. companies are now dominating the Europeans' Internet experience (CommerceNet, 2001) and will continue to do so in the near term.

From the above paragraphs and relevant literature citations, it is clear that Internet usage in general, and online retailing and purchasing, in particular are growing at an incredible rate, especially in modern, industrialized economies. This fact begs the question: How will retailing be effected and what will companies have to do to survive this new reality? It could be that Fred Crawford, an analyst of online marketing and brought in to serve on a roundtable panel by Ernst \& Young, may have hit the nail on the head when he said: "The physical world and the online world are coming together - they're blending - and the winners will be those companies that create synergy between online and offline retailing" (Ernst \& Young, 2001).

Undoubtedly, the most exciting concepts may be yet to come in online retailing, but listening to customers who shop/purchase in either an online or offline retailing environment is fundamental to survival. In face-to-face retailing, an astute seller can probe a shoppers/purchasers perceptions. That's tougher to do in online retailing. But it's just as important. Thus, online retailing can be another intelligence-gathering means to acquire a keen understanding of consumer motives, behaviors, and preferences. Retailers could then apply prescriptive measures to overcome consumer objections that could make both their brick-and-mortar stores and websites more compelling. As a fundamental component of the marketing concept, online retailers need to listen to those who have used the Internet for shopping - just as they would for their in-store shoppers - and attempt to understand their perceptions and concerns. This may sound easy, but when one considers that online retailers can sell to the world, that means that they must consider the differences in perceptions held by a host of online purchasers located in other geographic arenas. 


\section{Purpose Of The Study}

For the purpose of this study, the researchers sought to compare how citizens in the U.S. and the E.U.: (1) use the Internet for online shopping and probe their general perceptions of online shopping; and, more definitely, (2) assess their perceptions of products based on the product's country of origin. Because the U.S., E.U., and Japan are the countries whose producers enjoy the greatest global sales for manufactured goods, the researchers focused on the perceptions of products originating from those countries. Armed with findings such as provided in this empirical research project, the researchers felt that they might aid U.S. online sellers target their advertising messages to online shoppers either in the U.S. or abroad. At a minimum, it is hoped that the study will cause professionals in academe and in the commercial sector to ponder the issues raised herein.

\section{Research Methodology}

The population for this study was selected for convenience as two of the researchers found themselves in Europe - teaching as J. William Fulbright Distinguished Chairs at the Portuguese Catholic University in Lisbon. Using that assignment as a research platform, they developed a research instrument to be conjointly administered to a selected group of adults in Europe and the United States. Both groups - in the U.S. and the E.U. - were mainly students majoring in business administration, but a few from each geographic area were from outside of academe.

The questionnaire consisted of 47 questions, including 7 demographic questions. Not all of the questionnaire was devoted to seeking responses to online e-commerce issues, as some related to public trade policies of the U.S. and E.U. and immigration issues. Gathered data not used for this paper are reserved for future presentation and/or publication.

After administering the questionnaire, gathered data from each questionnaire was entered into the SPSS statistical software, then compiled and treated. These statistical treatments yielded descriptive statistics. Additionally, cross tabulations were accomplished with resulting chi-squares. The cross-tabulations that were computed were made relating to e-commerce using limited demographic features. The findings focus only on descriptive statistics that would have meaning to the layman and cross-tabulated data is discussed, especially as it relates directly to the nationality of the respondents and to their gender.

\section{Findings}

\subsection{Demographic Features Of The Population Studied}

The research instrument was completed by a total of 268 people. Of that number, 146 ( 74 men and 72 women) were from the U.S., and 108 ( 75 men and 33 women) from the E.U. An additional 13 ( 4 men and 9 women) participants completing the questionnaire self-identified themselves as "Other" - that is, not from the U.S. nor from the E.U. The researchers noted that these "Other" participants were from either countries on the continents of South America or Africa. With respect to the gender of the total respondents from all countries, 154 were male and 114 were female. With respect to the age of the total respondents, most (81\%) were under the of 35 while a far fewer number (19\%) were over 35. For education levels, the respondents indicated that $10.8 \%$ of the total respondents from all geographic areas had some high school education or were high school graduates. A far larger percentage (71.3\%) said that they had either some college/university education or were graduates thereof. Sixteen percent indicated that they held post-graduate degrees. In terms of individual income, the majority $(80 \%)$ of the total respondents self-reported an individual annual income level of less than 40,000 while $20 \%$ reported incomes above 40,000 (either expressed in US\$ or EU_). 


\subsection{Experiences And Perceptions Of Online Retailing}

Computing Location. The research instrument asked the question: "Where do you use the computer the most?" The following table shows the distribution of the findings obtained from that question. The responses to the question most likely reflect that more Americans have computers in their homes than do Europeans. Additionally, a crosstabulation of the data showed that U.S. women use computers mostly at work, but U.S. men use them mostly at home. E.U. respondents of both genders overwhelmingly (>85\%) report that they use computers mostly at work. Those classifying themselves as "Other" were nearly equally divided where they use the computer, at work or at home.

\begin{tabular}{|l|c|c|c|}
\hline \multirow{2}{*}{ Response Category } & \multicolumn{3}{|c|}{ Number of Respondents / Percentage of Respondents } \\
\cline { 2 - 4 } & U.S. & E.U. & Other \\
\hline At Work & $59 / 40.4 \%$ & $95 / 88.0 \%$ & $5 / 38.5 \%$ \\
\hline At Home & $73 / 50.0 \%$ & $12 / 11.1 \%$ & $6 / 46.2 \%$ \\
\hline Other Location (i.e., school, etc.) & $13 / 8.9 \%$ & $0 / .0 \%$ & $2 / 15.4 \%$ \\
\hline Do Not Use a Computer & $1 / .7 \%$ & $1 / .9 \%$ & $0 / .0 \%$ \\
\hline TOTAL & $146 / 100 \%$ & $108 / 100 \%$ & $13 / 100 \%$ \\
\hline
\end{tabular}

Purpose for Using a Computer. The questionnaire sought a response to the question: "In what way do you use a computer the most?" The following table indicates the responses for each computer utilization category. Crosstabs of the data showed that U.S. men primarily use the computer for Internet research, but U.S. women use it mostly for word processing. E.U. men and women, however, both use it mainly for word processing yet they differ on the secondary use with E.U. men reporting they use it for Internet research while E.U. women say that they use it for purposes of accounting/record-keeping.

\begin{tabular}{|l|c|c|c|}
\hline \multirow{2}{*}{ Response Category } & \multicolumn{2}{|c|}{ Number of Respondents / Percentage of Respondents } \\
\cline { 2 - 4 } & U.S. & E.U. & Other \\
\hline Word Processing & $57 / 39.0 \%$ & $57 / 52.8 \%$ & $7 / 53.8 \%$ \\
\hline E-Mail & $28 / 19.2 \%$ & $12 / 11.1 \%$ & $1 / 7.7 \%$ \\
\hline Accounting/Record-keeping & $16 / 11.0 \%$ & $16 / 14.8 \%$ & $1 / 7.7 \%$ \\
\hline Internet Use (i.e., research, etc.) & $40 / 27.4 \%$ & $18 / 16.7 \%$ & $4 / 30.8 \%$ \\
\hline Recreation/Games & $2 / 0.9 \%$ & $0 / .0 \%$ & $0 / .0 \%$ \\
\hline Do Not Use a Personal Computer & $3 / 2.5 \%$ & $5 / 4.6 \%$ & $0 / .0 \%$ \\
\hline TOTAL & $146 / 100 \%$ & $108 / 100 \%$ & $13 / 100 \%$ \\
\hline
\end{tabular}

Internet Purchase Experience. The research instrument asked the following question: "How many times have you used the Internet to purchase products in the last year?" The percentage responses of participants are provided in the following table. Most (65\% to 69\%) U.S. men and women report that they have used the Internet for purchases from 1 to 10 times during the past year. About half (48\%) of E.U. women and 56\% of E.U. men made from 1 to 10 Internet purchases last year. Interestingly, about double the number of E.U. men had never used the Internet for purchasing when contrasted with the Internet purchases of U.S. men. One-third of U.S. women indicated that they had never purchased online, and $46 \%$ of E.U. women had also never purchased items online.

\begin{tabular}{|l|c|c|c|}
\hline \multirow{2}{*}{ Response Category } & \multicolumn{2}{|c|}{ Number of Respondents / Percentage of Respondents } \\
\cline { 2 - 4 } & U.S. & E.U. & Other \\
\hline 1 to 5 Times & $78 / 53.4 \%$ & $47 / 43.5 \%$ & $6 / 46.2 \%$ \\
\hline 6 to 10 Times & $20 / 13.7 \%$ & $11 / 10.2 \%$ & $2 / 15.4 \%$ \\
\hline 11 or more times & $11 / 7.5 \%$ & $9 / 8.3 \%$ & $3 / 23.1 \%$ \\
\hline Never shopped on the Internet & $37 / 25.3 \%$ & $41 / 38.0 \%$ & $2 / 15.4 \%$ \\
\hline TOTAL & $146 / 100 \%$ & $108 / 100 \%$ & $13 / 100 \%$ \\
\hline
\end{tabular}


Internet Price Competitiveness. The following table was constructed from the responses to the question: "Do you agree/disagree that the prices for products available on the Internet are competitive with those offered by local retailers?" Most (85\%) U.S. men agree that Internet prices are competitive but U.S. women are less sure at $69 \%$. Although the percentages are somewhat less, E.U. men and women also agree that Internet prices are competitive. The data shows that the same can be said of those who classified themselves as "Other."

\begin{tabular}{|l|c|c|c|}
\hline \multirow{2}{*}{ Response Category } & \multicolumn{3}{|c|}{ Number of Respondents / Percentage of Respondents } \\
\cline { 2 - 4 } & U.S. & E.U. & Other \\
\hline Agree & $113 / 77.4 \%$ & $70 / 64.8 \%$ & $8 / 61.5 \%$ \\
\hline Disagree & $5 / 3.4 \%$ & $14 / 13.0 \%$ & $3 / 23.1 \%$ \\
\hline Don't Know / No Opinion & $28 / 19.2 \%$ & $24 / 22.2 \%$ & $2 / 15.4 \%$ \\
\hline TOTAL & $146 / 100 \%$ & $108 / 100 \%$ & $13 / 100 \%$ \\
\hline
\end{tabular}

Online Product Variety. The data presented in the following table was derived from the question: "Do you agree/disagree that the selection of products offered on the Internet is a as good or better than the selection of products offered by local retailers?" Crosstabulated data shows that most men from all three geographic regions felt that product variety was just as good or better offered for sale online as could be found at local retailing establishments. However, women from all three geographic locations were less sure.

\begin{tabular}{|l|c|c|c|}
\hline \multirow{2}{*}{ Response Category } & \multicolumn{3}{|c|}{ Number of Respondents / Percentage of Respondents } \\
\cline { 2 - 4 } & U.S. & E.U. & Other \\
\hline Agree & $84 / 57.5 \%$ & $56 / 58.4 \%$ & $5 / 38.5 \%$ \\
\hline Disagree & $20 / 13.7 \%$ & $28 / 25.9 \%$ & $3 / 23.1 \%$ \\
\hline Don't Know / No Opinion & $42 / 28.8 \%$ & $24 / 22.2 \%$ & $5 / 38.5 \%$ \\
\hline TOTAL & $146 / 100 \%$ & $108 / 100 \%$ & $13 / 100 \%$ \\
\hline
\end{tabular}

Internet Security as a Possible Inhibitor to Online Purchasing. With respect to Internet security using credit card numbers as the form of payment, the following question was posed which led to the construction of the following table: "Do you agree/disagree that when making purchases on the Internet adequate credit card security is provided?" Across the board, men from all three regions were more confident in using credit cards on the Internet than their female counterparts. E.U. women were the most doubtful of using credit cards for Net purchases.

\begin{tabular}{|l|c|c|c|}
\hline \multirow{2}{*}{ Response Category } & \multicolumn{3}{|c|}{ Number of Respondents / Percentage of Respondents } \\
\cline { 2 - 4 } & U.S. & E.U. & Other \\
\hline Agree & $74 / 50.7 \%$ & $50 / 46.3 \%$ & $6 / 46.2 \%$ \\
\hline Disagree & $26 / 17.8 \%$ & $30 / 27.8 \%$ & $3 / 23.1 \%$ \\
\hline Don't Know / No Opinion & $46 / 31.5 \%$ & $28 / 25.9 \%$ & $4 / 30.8 \%$ \\
\hline TOTAL & $146 / 100 \%$ & $108 / 100 \%$ & $13 / 100 \%$ \\
\hline
\end{tabular}

Delivery Time as a Possible Inhibitor to Online Shopping. The data is the following table reflects the respondents' perceptions regarding what could be an Internet shopping inhibitor - the time it takes to receive a product after ordering it. The data was gathered from the question: "Do you agree/disagree that the additional delivery time for products purchased on the Internet is no hindrance to shopping on the Internet?" Most European respondents felt that the waiting time to receive Internet purchases was not a major barrier for online shopping. American women (36\%) did not feel that delivery time adversely affected online shopping, but $46 \%$ of their male counterparts thought it did. 


\begin{tabular}{|l|c|c|c|}
\hline \multirow{2}{*}{ Response Category } & \multicolumn{2}{|c|}{ Number of Respondents / Percentage of Respondents } \\
\cline { 2 - 4 } & U.S. & E.U. & Other \\
\hline Agree & $54 / 37.0 \%$ & $55 / 50.9 \%$ & $5 / 38.5 \%$ \\
\hline Disagree & $60 / 41.1 \%$ & $34 / 39.1 \%$ & $3 / 23.1 \%$ \\
\hline Don't Know / No Opinion & $32 / 21.9 \%$ & $19 / 17.0 \%$ & $5 / 38.4 \%$ \\
\hline TOTAL & $146 / 100 \%$ & $108 / 100 \%$ & $13 / 100 \%$ \\
\hline
\end{tabular}

\subsection{Country Of Origin}

Country of Origin and Brand Name Awareness. The participating respondents' perceptions delineated in the following table were obtained from the question: "Do you usually know the country where a product was manufactured/originated by the product's brand name?" Across the board, men from all three geographic regions indicated more awareness of a product's country of origin based on its brand than did their female counterparts. Of all men or women from each region, American women were less likely to associate a brand name with a country of origin.

\begin{tabular}{|l|c|c|c|}
\hline \multirow{2}{*}{ Response Category } & \multicolumn{3}{|c|}{ Number of Respondents / Percentage of Respondents } \\
\cline { 2 - 4 } & U.S. & E.U. & Other \\
\hline Always & $3 / 2.1 \%$ & $7 / 6.5 \%$ & $2 / 15.4 \%$ \\
\hline Almost Always & $27 / 18.5 \%$ & $34 / 31.5 \%$ & $3 / 23.1 \%$ \\
\hline Sometimes & $93 / 63.7 \%$ & $61 / 56.5 \%$ & $6 / 46.2 \%$ \\
\hline Never & $23 / 15.8 \%$ & $6 / 5.6 \%$ & $2 / 15.4 \%$ \\
\hline TOTAL & $146 / 100 \%$ & $108 / 100 \%$ & $13 / 100 \%$ \\
\hline
\end{tabular}

Country of Origin Awareness. The data in the following table were obtained from the responses to the question: "When you shop the Internet for products do you pay attention to the product's country of origin?" Similarly to the crosstab above, men from all three responding regions indicated that they pay more attention to where a product is from than do women. Overall American men and women are less attentive to country of origin than those men and women from the E.U.

\begin{tabular}{|l|c|c|c|}
\hline \multirow{2}{*}{ Response Category } & \multicolumn{3}{|c|}{ Number of Respondents / Percentage of Respondents } \\
\cline { 2 - 4 } & U.S. & E.U. & Other \\
\hline Always & $7 / 4.8 \%$ & $17 / 15.7 \%$ & $3 / 23.1 \%$ \\
\hline Almost Always & $13 / 8.9 \%$ & $26 / 24.1 \%$ & $0 / .0 \%$ \\
\hline Sometimes & $76 / 52.1 \%$ & $53 / 49.1 \%$ & $5 / 38.5 \%$ \\
\hline Never & $50 / 34.2 \%$ & $12 / 11.1 \%$ & $4 / 30.8 \%$ \\
\hline TOTAL & $146 / 100 \%$ & $108 / 100 \%$ & $13100 \%$ \\
\hline
\end{tabular}

Influence of Country of Origin and Decision to Purchase. The data in the following table was obtained from the research question: "Do you agree/disagree that a product's country of origin influences your Internet purchase decision?" This question is looking for a bias in purchasing behavior. It did not find that bias in the responses gleaned from the American sample. That's because most of them (50\% of U.S. men and $67 \%$ of U.S. women) indicated that they were not influenced by a product's country of origin when making a purchase. European responses, however, did indicate a bias with $56 \%$ of the E.U. men and 58\% of E.U. women indicating that a product's country of origin affected their purchase decision. Most respondents in the "Other" category either felt that country of origin made no difference or they didn't know if it did or not. 


\begin{tabular}{|l|c|c|c|}
\hline \multirow{2}{*}{ Response Category } & \multicolumn{3}{|c|}{ Number of Respondents / Percentage of Respondents } \\
\cline { 2 - 4 } & U.S. & E.U. & Other \\
\hline Agree & $45 / 30.8 \%$ & $61 / 56.5 \%$ & $4 / 30.8 \%$ \\
\hline Disagree & $85 / 58.2 \%$ & $44 / 40.7 \%$ & $6 / 46.2 \%$ \\
\hline Don't Know / No Opinion & $16 / 11.0 \%$ & $3 / 2.8 \%$ & $3 / 23.1 \%$ \\
\hline TOTAL & $146 / 100 \%$ & $108 / 100 \%$ & $3 / 100 \%$ \\
\hline
\end{tabular}

Country of Origin and Pricing. The following table was constructed from the data gleaned from the question: "When you compare prices of products on the Internet, do you almost always feel that products from____ are the most expensive? Crosstabs by gender and country showed that men and women from all regions, except U.S. women, were fairly evenly split as to how they viewed the pricing of Internet products from the countries given. The majority $(56 \%)$ of American women indicated that they were unsure of pricing of products and their source.

\begin{tabular}{|l|c|c|c|}
\hline \multirow{2}{*}{ Country of Origin } & \multicolumn{3}{|c|}{ Number of Respondents / Percentage of Respondents } \\
\cline { 2 - 4 } & U.S. & E.U. & Other \\
\hline U.S. & $34 / 23.3 \%$ & $26 / 24.1 \%$ & $4 / 30.8 \%$ \\
\hline E.U. & $32 / 21.9 \%$ & $33 / 30.6 \%$ & $4 / 30.8 \%$ \\
\hline Japan & $19 / 13.0 \%$ & $11 / 10.2 \%$ & $1 / 7.7 \%$ \\
\hline Don't Know / No Opinion & $61 / 41.8 \%$ & $38 / 35.2 \%$ & $4 / 30.8 \%$ \\
\hline TOTAL & $146 / 100 \%$ & $108 / 100 \%$ & $13 / 100 \%$ \\
\hline
\end{tabular}

Country of Origin and Perception of Product Quality. Responses compiled from the question: "When you compare product quality, do you almost always feel that products from have the highest quality?" were used to construct the following table. The highest percentage of U.S. men felt that Japanese products offered the highest quality while the highest percentage of U.S. women said they didn't know which country's products had the highest quality. Europeans, however, did know. Both E.U. men and women felt that E.U. products were superior to either U.S. or Japanese products and that U.S. products possessed the lowest quality.

\begin{tabular}{|l|c|c|c|}
\hline \multirow{2}{*}{ Country of Origin } & \multicolumn{3}{|c|}{ Number of Respondents / Percentage of Respondents } \\
\cline { 2 - 4 } & U.S. & E.U. & Other \\
\hline U.S. & $28 / 19.2 \%$ & $7 / 6.5 \%$ & $2 / 15.4 \%$ \\
\hline E.U. & $16 / 11.0 \%$ & $51 / 47.2 \%$ & $4 / 30.8 \%$ \\
\hline Japan & $46 / 31.5 \%$ & $31 / 28.7 \%$ & $6 / 38.5 \%$ \\
\hline Don't Know / No Opinion & $56 / 38.4 \%$ & $19 / 17.6 \%$ & $2 / 15.4 \%$ \\
\hline TOTAL & $146 / 100 \%$ & $108 / 100 \%$ & $13 / 100 \%$ \\
\hline
\end{tabular}

Country of Origin and Perception of Product Features. The following table was constructed from the data gleaned from asking the research question: "When you compare product features, do you almost always feel that the products from ___ have the most desirable features? The largest percentage of U.S. men felt that products from Japan offered the best features. However, most (53\%) of American women reported that they didn't know which country's products offered the most desirable features. Like their American male counterparts, the largest percentage of E.U. males indicated that Japanese products had the best features. E.U. women, however, were fairly evenly split over the features offered by products from either the U.S., E.U., or Japan. Interestingly, the majority (>50\%) of either male or female respondents in the "Other" category felt that products from the U.S. had the best features. 


\begin{tabular}{|l|c|c|c|}
\hline \multirow{2}{*}{ Country of Origin } & \multicolumn{3}{|c|}{ Number of Respondents / Percentage of Respondents } \\
\cline { 2 - 4 } & U.S. & E.U. & Other \\
\hline U.S. & $26 / 17.8 \%$ & $20 / 18.5 \%$ & $7 / 53.8 \%$ \\
\hline E.U. & $15 / 10.3 \%$ & $33 / 30.6 \%$ & $1 / 7.7 \%$ \\
\hline Japan & $48 / 32.9 \%$ & $35 / 32.4 \%$ & $3 / 23.1 \%$ \\
\hline Don't Know / No Opinion & $57 / 39.0 \%$ & $20 / 18.5 \%$ & $2 / 15.4 \%$ \\
\hline TOTAL & $146 / 100 \%$ & $108 / 100 \%$ & $13 / 100 \%$ \\
\hline
\end{tabular}

Country of Origin and Perception of Ease of Using Product. The following table was created from the collective responses to the question: "When you compare a product's ease of use, do you almost always feel that products from are the easiest to use?" The highest percentage (49\%) of U.S. males felt that U.S. products were easiest to use whereas the majority of U.S. females $(65 \%)$ indicated that they did not know. E.U. males were fairly evenly split between U.S. and E.U. products. However, E.U. women felt that when comparing only U.S. and E.U. products, U.S. were much easier to use. But similar to their U.S. counterparts the largest percentage (39\%) of E.U. women indicated that they did not know which country's products were easiest to use. The "Other" respondents felt that U.S. and Japanese products were virtually the same when it came to ease of use. Interestingly, however, not one "Other" respondent felt that E.U. products were easiest to use.

\begin{tabular}{|l|c|c|c|}
\hline \multirow{2}{*}{ Country of Origin } & \multicolumn{3}{|c|}{ Number of Respondents / Percentage of Respondents } \\
\cline { 2 - 4 } & U.S. & E.U. & Other \\
\hline U.S. & $54 / 37.0 \%$ & $36 / 33.3 \%$ & $7 / 53.8 \%$ \\
\hline E.U. & $8 / 5.5 \%$ & $25 / 23.1 \%$ & $0 / .0 \%$ \\
\hline Japan & $2114.4 \%$ & $20 / 18.5 \%$ & $6 / 46.2 \%$ \\
\hline Don't Know / No Opinion & $63 / 43.2 \%$ & $27 / 25.0 \%$ & $0 / .0 \%$ \\
\hline TOTAL & $146 / 100 \%$ & $108 / 100 \%$ & $13 / 100 \%$ \\
\hline
\end{tabular}

Country of Origin and Perception of Product Style. The data in the next table was compiled by asking the question: "When you compare a product's style, do you almost always feel that products from have the most style?" Of the three countries listed in the response categories for this question, both U.S. men and women felt that E.U. products had the most style. However, again the majority of American women indicated that they didn't know which country's products offered the most in terms of style. E.U. men and women were relatively certain which country's products offered the most style. That's because $72 \%$ of E.U. men and $55 \%$ of E.U. women felt that E.U. products were much more stylish than either U.S. or Japanese products. Seventy-five percent of the respondents in the "Other" category felt that E.U. products were more stylish, while $44 \%$ of their female counterparts indicated that U.S. products had the most style.

\begin{tabular}{|l|c|c|c|}
\hline \multirow{2}{*}{ Country of Origin } & \multicolumn{3}{|c|}{ Number of Respondents / Percentage of Respondents } \\
\cline { 2 - 4 } & U.S. & E.U. & Other \\
\hline U.S. & $25 / 17.1 \%$ & $22 / 20.4 \%$ & $5 / 38.5 \%$ \\
\hline E.U. & $53 / 36.3 \%$ & $72 / 66.7 \%$ & $6 / 46.2 \%$ \\
\hline Japan & $16 / 11.0 \%$ & $1 / .9 \%$ & $2 / 15.4 \%$ \\
\hline Don't Know / No Opinion & $51 / 34.9 \%$ & $13 / 12.0 \%$ & $0 / .0 \%$ \\
\hline TOTAL & $146 / 100 \%$ & $108 / 100 \%$ & $13 / 100 \%$ \\
\hline
\end{tabular}

Country of Origin and Perception of Product Prestige. The following table was built from data gleaned from the research question: "When you compare a product's prestige, do you almost always feel that products from have the best/most prestigious image? Crosstabs show that U.S. men are split between the image of U.S. and E.U. products at $34 \%$ each. Again, the largest percentage (49\%) of U.S. women don't know which country's 
products carry the most prestige. E.U. men and women, however, are relatively certain which country's products convey prestige $-57 \%$ of E.U. men and $46 \%$ of E.U. women felt that E.U. products have the most prestige. All responding groups felt that Japanese products conveyed the least prestige.

\begin{tabular}{|l|c|c|c|}
\hline \multirow{2}{*}{ Country of Origin } & \multicolumn{3}{|c|}{ Number of Respondents / Percentage of Respondents } \\
\cline { 2 - 4 } & U.S. & E.U. & Other \\
\hline U.S. & $41 / 28.1 \%$ & $26 / 24.1 \%$ & $4 / 30.8 \%$ \\
\hline E.U. & $38 / 26.0 \%$ & $58 / 53.7 \%$ & $5 / 38.5 \%$ \\
\hline Japan & $21 / 14.4 \%$ & $12 / 11.1 \%$ & $2 / 15.4 \%$ \\
\hline Don't Know / No Opinion & $46 / 31.5 \%$ & $12 / 11.1 \%$ & $2 / 15.4 \%$ \\
\hline TOTAL & $146 / 100 \%$ & $108 / 100 \%$ & $13 / 100 \%$ \\
\hline
\end{tabular}

Country of Origin and Perception of Advertising Effectiveness. The data entered into the next table was derived from asking the research question: "When you compare a product's advertising message, do you almost always feel that products from ___ have the most effective advertising message? Respondents from all countries and both genders indicated that the most effective advertising for products emanated from the U.S.

\begin{tabular}{|l|c|c|c|}
\hline \multirow{2}{*}{ Country of Origin } & \multicolumn{3}{|c|}{ Number of Respondents / Percentage of Respondents } \\
\cline { 2 - 4 } & U.S. & E.U. & Other \\
\hline U.S. & $86 / 58.9 \%$ & $65 / 60.2 \%$ & $9 / 69.2 \%$ \\
\hline E.U. & $8 / 5.5 \%$ & $26 / 24.1 \%$ & $2 / 15.4 \%$ \\
\hline Japan & $4 / 2.7 \%$ & $3 / 2.8 \%$ & $0 / .0 \%$ \\
\hline Don't Know / No Opinion & $48 / 32.9 \%$ & $14 / 13.0 \%$ & $2 / 15.4 \%$ \\
\hline TOTAL & $146 / 100 \%$ & $108 / 100 \%$ & $13 / 100 \%$ \\
\hline
\end{tabular}

\section{Conclusions}

\subsection{Perceptions Of Online Shopping}

- $\quad$ Europeans tend to use computers more at work; Americans more at home.

- A majority of Europeans and Americans agree that pricing is competitive and variety is as good or better in online retailing when compared to traditional in-store retailing.

- Half of Americans feel that online credit card security is adequate. Slightly less than half of Europeans and "Others" agree with that presumption.

- $\quad$ Half of Europeans feel that the additional delivery time for online purchases is not a hindrance to buying online. However, a fairly substantial group of both U.S. and E.U. respondents believed that additional delivery time was a hindrance.

\subsection{Country Of Origin Perceptions}

- More Europeans are aware and pay attention to a product's country of origin when shopping on the Internet than do Americans.

- A majority of Europeans are influenced by a product's country of origin for their online purchases whereby the majority of Americans are not so influenced.

- $\quad$ Europeans tend to believe that E.U. products are the most expensive, but are of greater quality and are more stylish than products from either the U.S. or Japan. Americans are split in their beliefs as they view U.S. products as the most expensive, while Japanese products have the highest quality, and European products have more style. 
- While Europeans and Americans both felt that Japanese products have the most desirable features, they felt that U.S. products were easier to use than either European or Japanese products.

- With respect to product image/prestige, Europeans believe that their products convey the most prestigious image while Americans are split between European and American products.

- $\quad$ All study participants felt that U.S. advertising campaigns were more effective than either the European or Japanese.

\section{References}

1. Clark, Matthew. (2002). "U.S. e-commerce sales reach all time high", Electronic News (February 20, 2002). Available on the Internet at http://www.enn.ie/news.html?code $=6251954$.

2. CommerceNet. (2002). "Industry statistics - worldwide internet population", Available on the Internet at http://www.commerce.net/research/stats/wwstats.html.

3. CommerceNet. (2001). "Industry statistics - worldwide industry statistics", Available on the Internet at http://www.commerce.net/research/stats/indust.html.

4. $\quad$ Ernst \& Young. (2001). "Global online retailing: an Ernst \& Young special report".

5. European Telework Development. (2000). "A new geography of trade: implications of networked economy distances", Available on the Internet at wysiwyg://28/http://www.eto.org.uk/eustats/netdist-n.htm.

6. Gore, Albert, Jr. (1999). "A framework for global electronic commerce", Available on the Internet at http://iitf.doc.gov/eleccomm/ecomm.htm.

7. Hobley, Christopher. (2001). Just numbers: numbers on internet use, electronic commerce, IT and related figures for the European Community.

8. McDonald, Sheila. (2002). "Net shopping jumps 40 percent in Europe", Available on the Internet at http://www.enn.ie/news.html?code $=5578770$.

9. Pricewaterhousecoopers LLP. (2001). "E-retail intelligence system internet users consumer panel”, (January 2001). Available on the Internet at http://pweglobal.com/extweb/ncpressrelease.nsf/DocID/5D3A769118358D30895256A...

10. U.S. Department of Commerce, the Census Bureau. (2002). Retail e-commerce sales in fourth quarter 2001.

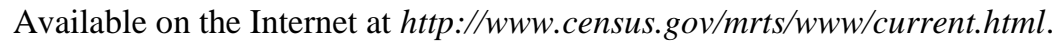

11. U.S. Department of Commerce, the Economics and Statistics Administration. (2002). "A nation online: how Americans are expanding their use of the internet", Available on the Internet at http://www.esa.doc.gov/508/esa/nationonline.htm. 